\title{
Which factors are associated with sarcopenia and frailty in elderly persons residing in the community?
}

\section{Abstract}

Objective: to broaden knowledge about the factors associated with sarcopenia and frailty in elderly persons residing in the community. Method: an integrative systematic review based on the PRISMA recommendations was carried out, using articles published from 2012 to March 2017 in the PubMED, SciELO, Virtual Health Library, CINAHL and Springer electronic databases with the following descriptors: frail elderly, sarcopenia and etiology and their synonyms. The articles identified by the initial search strategy were independently assessed by two researchers, according to the eligibility criteria, and the articles selected were evaluated for methodological quality. Results: the results of this survey show that frailty may be associated with sarcopenia, low serum vitamin $\mathrm{D}$ levels, anemia, subclinical hyperthyroidism in men, while the greatest evolution in women was for osteoporosis. An association between sarcopenia and advanced age was also observed, with worsening quality of life, physical-functional capacity, nutritional status and comorbidities, as well as an increased risk of death in sarcopenic elderly persons. Conclusion: this systematic review showed that low serum levels of vitamin $\mathrm{D}$ are associated with frailty and factors that predispose this condition. It is therefore important to monitor the serum levels of this vitamin in the elderly population, and it is suggested that new studies are carried out related to supplements of this vitamin in frail elderly persons.

Pontifícia Universidade Católica do Rio Grande do Sul, Instituto de Geriatria e Gerontologia, Escola de Medicina, Programa de Pós-graduação em Gerontologia Biomédica. Porto Alegre, Rio Grande do Sul, Brasil.

2 Universidade Regional do Noroeste do Estado do Rio Grande do Sul, Programa de graduação em Fisioterapia. Ijuí, Rio Grande do Sul, Brasil.

3 Universidade Regional do Noroeste do Estado do Rio Grande do Sul, Programa de Pós-graduação em Atenção Integral a Saúde. Ijuí, Rio Grande do Sul, Brasil.

Funding: Coordenação de Aperfeiçoamento de Pessoal de Nível Superior (CAPES), Edict 88882.1649312014-01, Scholarship PROEX.

Keywords: Frail Elderly. Sarcopenia. Etiology. Vitamin D.
Ana Paula Pillatt'

Rutiana Silva Patias ${ }^{2}$

Evelise Moraes Berlezi ${ }^{3}$ Rodolfo Herberto Schneider ${ }^{1}$ 


\section{INTRODUCTION}

During the aging process various physiological changes occur simultaneously in the different systems of the human body, associated with the accumulation of a wide variety of molecular and cellular damage'. In relation to the musculoskeletal system, aging leads to central and peripheral neuronal degeneration, muscular atrophy and increased adipose tissue in the muscle, and these changes increase the risk of dependence and disability ${ }^{2}$ and can encourage the emergence of sarcopenia.

Sarcopenia was initially described by Rosenberg ${ }^{3}$ as a reduction of overall muscle mass, which occurs throughout aging. Currently, this definition covers the reduction of muscle strength and physical performance, according to the consensus published by the European Working Group on Sarcopenia in Older People ${ }^{4}$. Sarcopenia leads to reduced quality of muscle contraction, strength and coordination of movements, predisposing the individual to functional decline, leading to disability and increased risk of falls and mortality ${ }^{5}$.

Sarcopenia can be associated with frailty, as observed in the study by Mijnarends et $\mathrm{al}^{6}$, which found a heightened risk of the condition of $60 \%$ among frail elderly persons aged 60-70, while among the non-frail elderly this risk was $10 \%$. This same study showed that in the elderly aged between 80 and 90 years there is also a heightened risk of $60 \%$ for sarcopenia; however, no difference was observed between frail and non-frail elderly.

Frailty has been widely studied in recent decades, causing the conceits regarding the condition to change. The most widely accepted definitions today are those suggested by Rockwood et $\mathrm{al}^{7}$ which combines frailty with disabilities and by Fried et a ${ }^{8}$ who defined the frailty syndrome as a spiraling decline in energy, supported by a tripod of aging-related changes; composed of sarcopenia, neuroendocrine dysregulation and immunological dysfunction'. As it is a physical syndrome, the frailty phenotype includes unintentional weight loss, weakness, low resistance and energy, slowness and a low level of physical activity $^{8}$. Like sarcopenia, frailty is also a predictive factor for increased dependence and death ${ }^{10}$.

Sarcopenia and frailty are conditions that arise from multiple factors that trigger interrelated events in a cause and effect relationship, which hinders an appropriate and effective therapeutic approach. There is therefore a need for scientific evidence on the subject that can elucidate the factors associated with sarcopenia and frailty and instigate hypotheses of cause and effect, with the perspective of guiding new research aimed at proposing more resolutive treatments for these conditions. In this context, the present study aimed to broaden knowledge about the factors associated with sarcopenia and frailty in elderly residents of the community.

\section{METHOD}

An integrative systematic review was carried out, based on the recommendations of PRISMA ${ }^{11}$, and which was registered in the international prospective register of systematic reviews under code CRD42017079102. The guiding question for the survey was: which factors are associated with sarcopenia and frailty among the elderly residing in the community? The search was conducted in April 2017, from articles published in the period from 2012 to March 2017 in the following electronic databases: PubMED, SciELO, Virtual Health Library, CINAHL and Springer. In order to search for the articles, we used as descriptors frail elderly, sarcopenia and etiology and their synonyms, according to Chart 1.

Chart 1. Search strategy. Porto Alegre, Rio Grande do Sul, 2017.

\begin{tabular}{|c|c|}
\hline & $\begin{array}{l}\text { "Frail Elderly"[Mesh] OR "Elderly, Frail" OR "Frail Elders" OR "Elder, Frail” OR "Elders, Frail" OR "Frail Elder" } \\
\text { OR "Functionally-Impaired Elderly" OR "Elderly, Functionally-Impaired" OR "Functionally Impaired Elderly" OR "Frail } \\
\text { Older Adults" OR "Adult, Frail Older" OR "Adults, Frail Older" OR "Frail Older Adult" OR "Older Adult, Frail" OR } \\
\text { "Older Adults, Frail" }\end{array}$ \\
\hline AND & "Sarcopenia"[Mesh] OR “Sarcopenias” \\
\hline AND & "Etiology" [Mesh] OR “Causality” OR “Causes” OR "Pathogenesis” \\
\hline
\end{tabular}


The articles identified by the search strategy were independently evaluated by two researchers. The first step in the selection of articles was the reading of titles and abstracts. The inclusion criteria were: original articles, elderly population and texts that addressed the etiology of sarcopenia or frailty. There was no restriction on the language of publication of articles. The exclusion criteria were: narrative review articles, with therapeutic interventions, populations with specific conditions or diseases, and hospitalized or institutionalized elderly. After the first selection and exclusion of duplicate articles, the researchers read the articles in full for data extraction and methodological quality analysis. When there was a divergence in selection, the evaluators discussed the issue until they arrived at a consensus.

In the extraction of data from the articles, the search for the following information was emphasized: study objective, type of study, sample, location where the study was carried out; and the main results presented were analyzed. The articles included were assessed for methodological quality through the scale of Loney et $\mathrm{al}^{12}$ for cross-sectional studies evaluating aspects related to the validity of the method, interpretation and applicability of the results; and the Newcastle-Ottawa Scale ${ }^{13}$ for cohort studies through evaluation of sample selection, comparability, and outcome. The two scales have a maximum score of eight points and higher values mean higher methodological quality.

\section{RESULTS}

A total of 219 articles were selected in the electronic databases PubMED, SciELO, Virtual Health Library, CINAHL and Springer. After initial reading, 11 articles were selected for final analysis. The processes performed in the selection of articles and the reasons for exclusion are described in Figure 1.

During the extraction of data from the selected articles carried out by researchers, the search for study objectives, methodologies used, sample size and gender of the subjects, country of research (Chart 2) and main results of each study were prioritized, with greater relevance given to statistically significant data (Chart 3).

In the evaluation of the methodological quality carried out by the two researchers (Chart 2), the articles obtained a score equal to or above average, which represents a good methodological quality of the level of scientific evidence. 


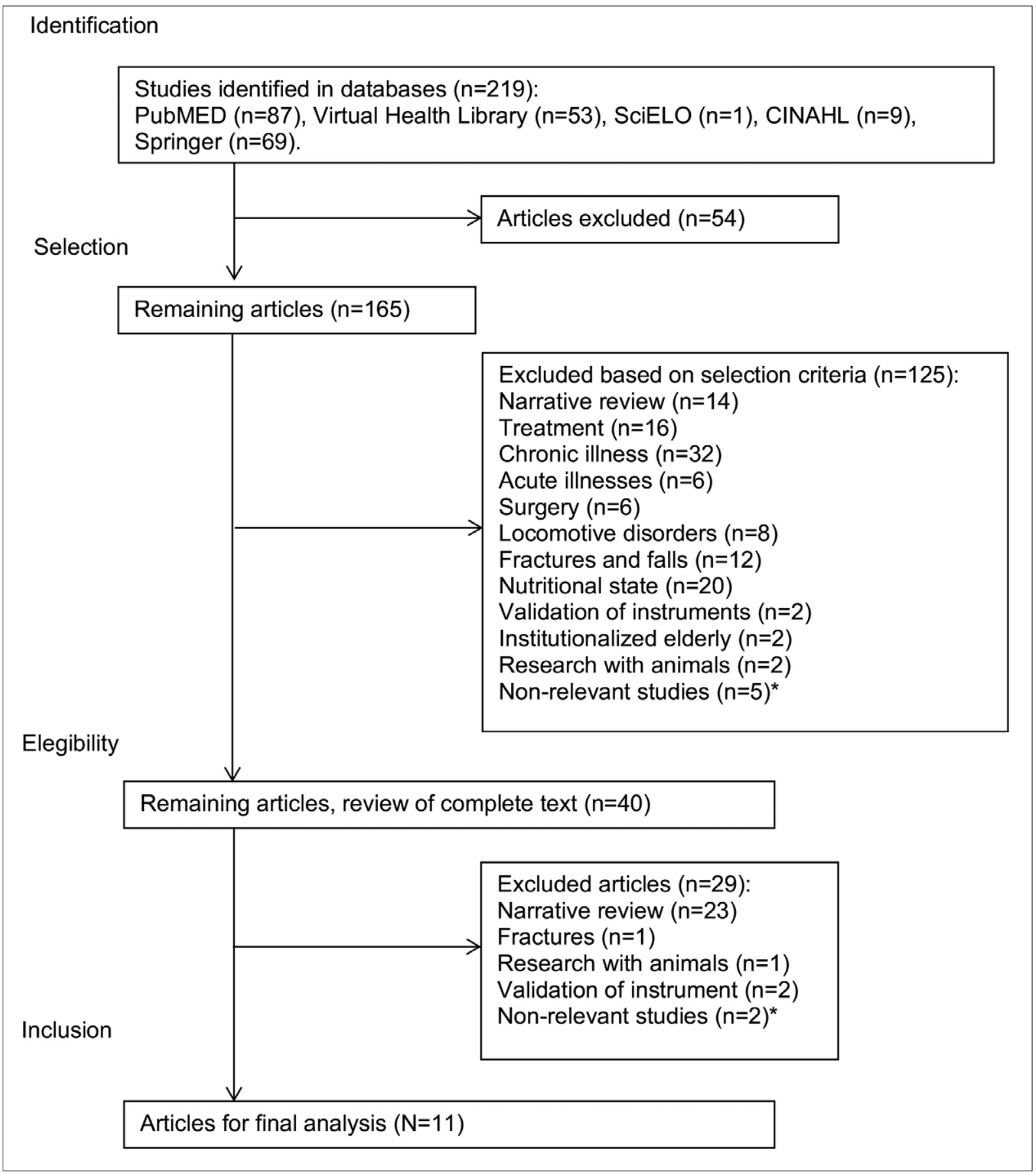

* Studies with no causal relationship with sarcopenia and frailty.

Figure 1. Flowchart of article selection. Porto Alegre, RS, 2017. 
Chart 2. Description of Articles selected for integrative review. Porto Alegre, RS, 2017.

\begin{tabular}{|c|c|c|c|c|c|}
\hline $\begin{array}{l}\text { Authors (Year) } \\
\text { Reference }\end{array}$ & Objective & $\begin{array}{l}\text { Type of } \\
\text { study }\end{array}$ & Sample & $\begin{array}{l}\text { Research } \\
\text { location }\end{array}$ & $\begin{array}{l}\text { Methodological } \\
\text { Quality }\end{array}$ \\
\hline $\begin{array}{l}\text { He, Liu, Tian, } \\
\text { Papasiano, Hu, Deng } \\
(2016)^{14}\end{array}$ & $\begin{array}{l}\text { To investigate the relationship } \\
\text { between sarcopenia and body } \\
\text { composition and osteoporosis in } \\
\text { cohorts of three different races. }\end{array}$ & $\begin{array}{l}\text { Cross- } \\
\text { sectional } \\
\text { study }\end{array}$ & $\begin{array}{l}17,891 \\
\text { individuals } \\
\text { of both } \\
\text { sexes }\end{array}$ & $\begin{array}{l}\text { USA and } \\
\text { China }\end{array}$ & $5 / 8^{* *}$ \\
\hline $\begin{array}{l}\text { Virgini, Rodondi, } \\
\text { Cawthon, Harrison, } \\
\text { Hoffman, Orwoll, } \\
\text { Ensrud, Bauer }(2015)^{15} \\
\end{array}$ & $\begin{array}{l}\text { To evaluate the associations } \\
\text { between subclinical thyroid } \\
\text { dysfunction and frailty and the } \\
\text { five subdomains of frailty. }\end{array}$ & $\begin{array}{l}\text { Cohort } \\
\text { study }\end{array}$ & 1455 men & USA & $6 / 8^{*}$ \\
\hline $\begin{array}{l}\text { Beaudart, Reginster, } \\
\text { Petermans, Gillain, } \\
\text { Quabron, Locquet, } \\
\text { Slomian, Buckinx, } \\
\text { Bruyère }(2015)^{16} \\
\end{array}$ & $\begin{array}{l}\text { To evaluate the prevalence of } \\
\text { sarcopenia and the relationship } \\
\text { between sarcopenia and } \\
\text { sociodemographic, clinical and } \\
\text { physical components. }\end{array}$ & $\begin{array}{l}\text { Cross- } \\
\text { sectional } \\
\text { study }\end{array}$ & $\begin{array}{l}534 \\
\text { individuals } \\
\text { of both } \\
\text { sexes }\end{array}$ & Belgium & $5 / 8^{* *}$ \\
\hline $\begin{array}{l}\text { Corona, Andrade, } \\
\text { Duarte, Lebrao } \\
(2015)^{17}\end{array}$ & $\begin{array}{l}\text { To explore the relationship } \\
\text { between anemia, hemoglobin } \\
\text { concentration and frailty } \\
\text { syndrome in the elderly. }\end{array}$ & $\begin{array}{l}\text { Cross- } \\
\text { sectional } \\
\text { study }\end{array}$ & $\begin{array}{l}1256 \\
\text { individuals } \\
\text { of both } \\
\text { sexes }\end{array}$ & Brazil & $7 / 8^{* *}$ \\
\hline $\begin{array}{l}\text { Serra-Prat, Papiol, } \\
\text { Monteis, Palomera, } \\
\text { Cabré }(2015)^{18}\end{array}$ & $\begin{array}{l}\text { Investigating the relationship } \\
\text { between plasma levels of } \\
\text { ghrelin and sarcopenia in the } \\
\text { elderly. }\end{array}$ & $\begin{array}{l}\text { Cross- } \\
\text { sectional } \\
\text { study }\end{array}$ & $\begin{array}{l}88 \\
\text { individuals } \\
\text { of both } \\
\text { sexes }\end{array}$ & Spain & $4 / 8^{* *}$ \\
\hline $\begin{array}{l}\text { Sternberg, Levin, } \\
\text { Dkaidek, Edelman, } \\
\text { Resnick, Menczel } \\
(2014)^{19} \\
\end{array}$ & $\begin{array}{l}\text { To examine the relationship } \\
\text { between frailty and osteoporosis } \\
\text { in elderly women living in the } \\
\text { community. }\end{array}$ & $\begin{array}{l}\text { Cohort } \\
\text { study }\end{array}$ & 235 women & Israel & $6 / 8^{*}$ \\
\hline $\begin{array}{l}\text { Chen, Yang, Chan, } \\
\text { Lee, Lu, Huang } \\
(2014)^{20}\end{array}$ & $\begin{array}{l}\text { To investigate the relationship } \\
\text { between serum selenium level } \\
\text { and skeletal muscle mass in } \\
\text { the elderly residing in the } \\
\text { community. }\end{array}$ & $\begin{array}{l}\text { Cross- } \\
\text { sectional } \\
\text { study }\end{array}$ & $\begin{array}{l}327 \\
\text { individuals } \\
\text { of both } \\
\text { sexes }\end{array}$ & Taiwan & $4 / 8^{* *}$ \\
\hline $\begin{array}{l}\text { Silva, Duarte, Santos, } \\
\text { Wong, Lebrão }(2014)^{21}\end{array}$ & $\begin{array}{l}\text { To examine the prevalence of } \\
\text { and factors associated with } \\
\text { sarcopenia in elderly residents of } \\
\text { São Paulo, Brazil. }\end{array}$ & $\begin{array}{l}\text { Cross- } \\
\text { sectional } \\
\text { study }\end{array}$ & $\begin{array}{l}1.149 \\
\text { individuals } \\
\text { of both } \\
\text { sexes }\end{array}$ & Brazil & $8 / 8^{* *}$ \\
\hline $\begin{array}{l}\text { Tieland, Brolsma, } \\
\text { Rousseau, Loon, } \\
\text { Groot }(2013)^{22}\end{array}$ & $\begin{array}{l}\text { Explore the association between } \\
\text { vitamin D intake and serum } \\
25(\mathrm{OH}) \mathrm{D} \text { status and muscle } \\
\text { mass, strength and physical } \\
\text { performance in a pre-frail and } \\
\text { frail elderly population. }\end{array}$ & $\begin{array}{l}\text { Cross- } \\
\text { sectional } \\
\text { study }\end{array}$ & $\begin{array}{l}127 \\
\text { individuals } \\
\text { of both } \\
\text { sexes }\end{array}$ & Holland & $5 / 8^{* *}$ \\
\hline $\begin{array}{l}\text { Landi, Jentoft, } \\
\text { Liperoti, Russo, } \\
\text { Giovannini, Tosato, } \\
\text { Capoluongo, Bernabei, } \\
\text { Onder }(2013)^{23}\end{array}$ & $\begin{array}{l}\text { To assess the impact of } \\
\text { sarcopenia on the risk of death } \\
\text { from all causes in a population } \\
\text { of frail elderly persons living in } \\
\text { a community. }\end{array}$ & $\begin{array}{l}\text { Cohort } \\
\text { study }\end{array}$ & $\begin{array}{l}197 \\
\text { individuals } \\
\text { of both } \\
\text { sexes }\end{array}$ & Italy & $6 / 8^{*}$ \\
\hline $\begin{array}{l}\text { Arango-Lopera, } \\
\text { Arroyo, Gutierrez- } \\
\text { Robledo, Perez- } \\
\text { Zepeda, Cesari } \\
(2013)^{24}\end{array}$ & $\begin{array}{l}\text { To determine the association } \\
\text { between sarcopenia and } \\
\text { mortality in a group of Mexican } \\
\text { elderly persons. }\end{array}$ & $\begin{array}{l}\text { Cohort } \\
\text { study }\end{array}$ & $\begin{array}{l}345 \\
\text { individuals } \\
\text { of both } \\
\text { sexes }\end{array}$ & Mexico & $7 / 8^{*}$ \\
\hline
\end{tabular}

* article score/total score of Newcastle-Ottawa scale; ** article score/total score of Loney scale. 


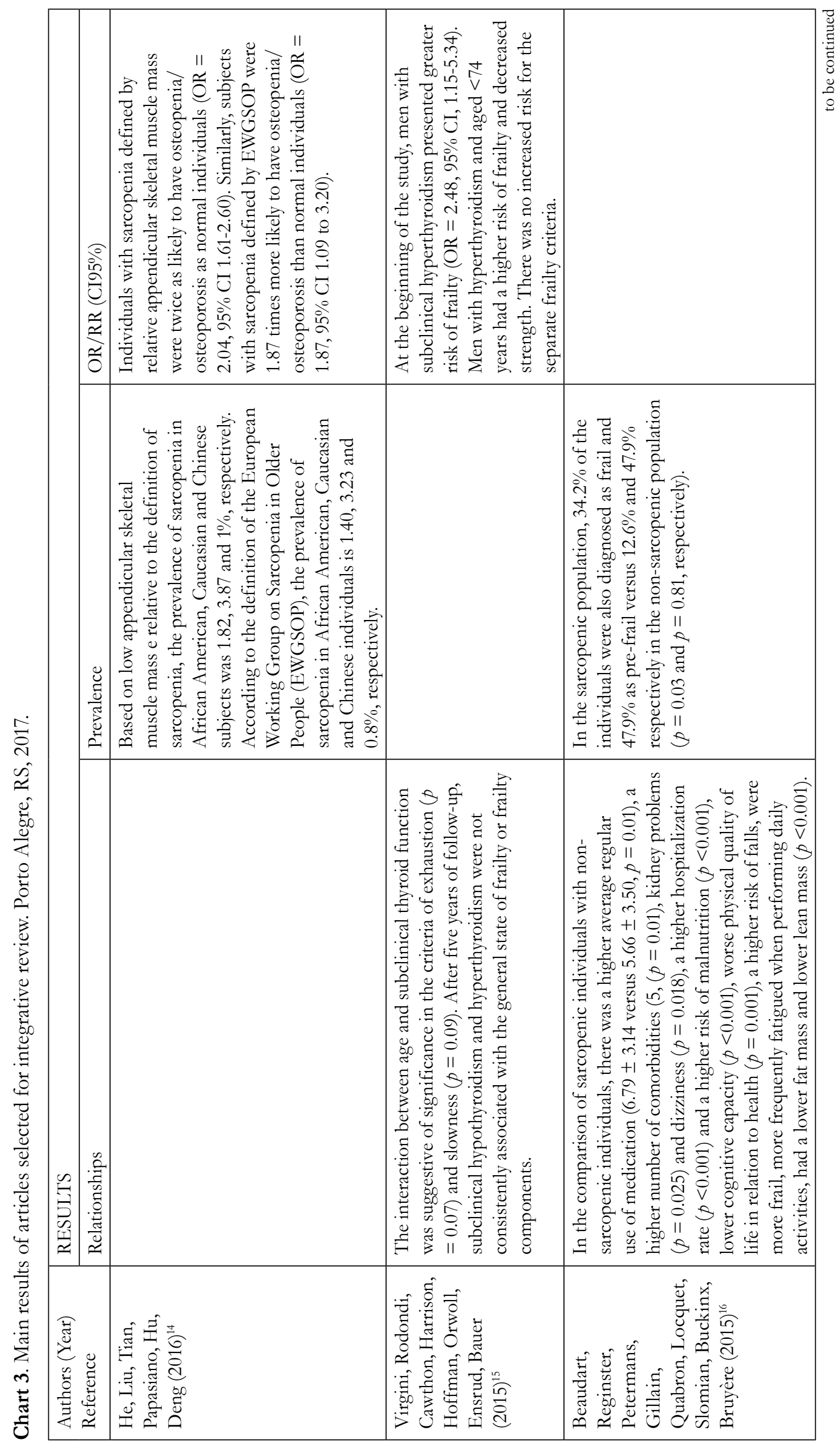




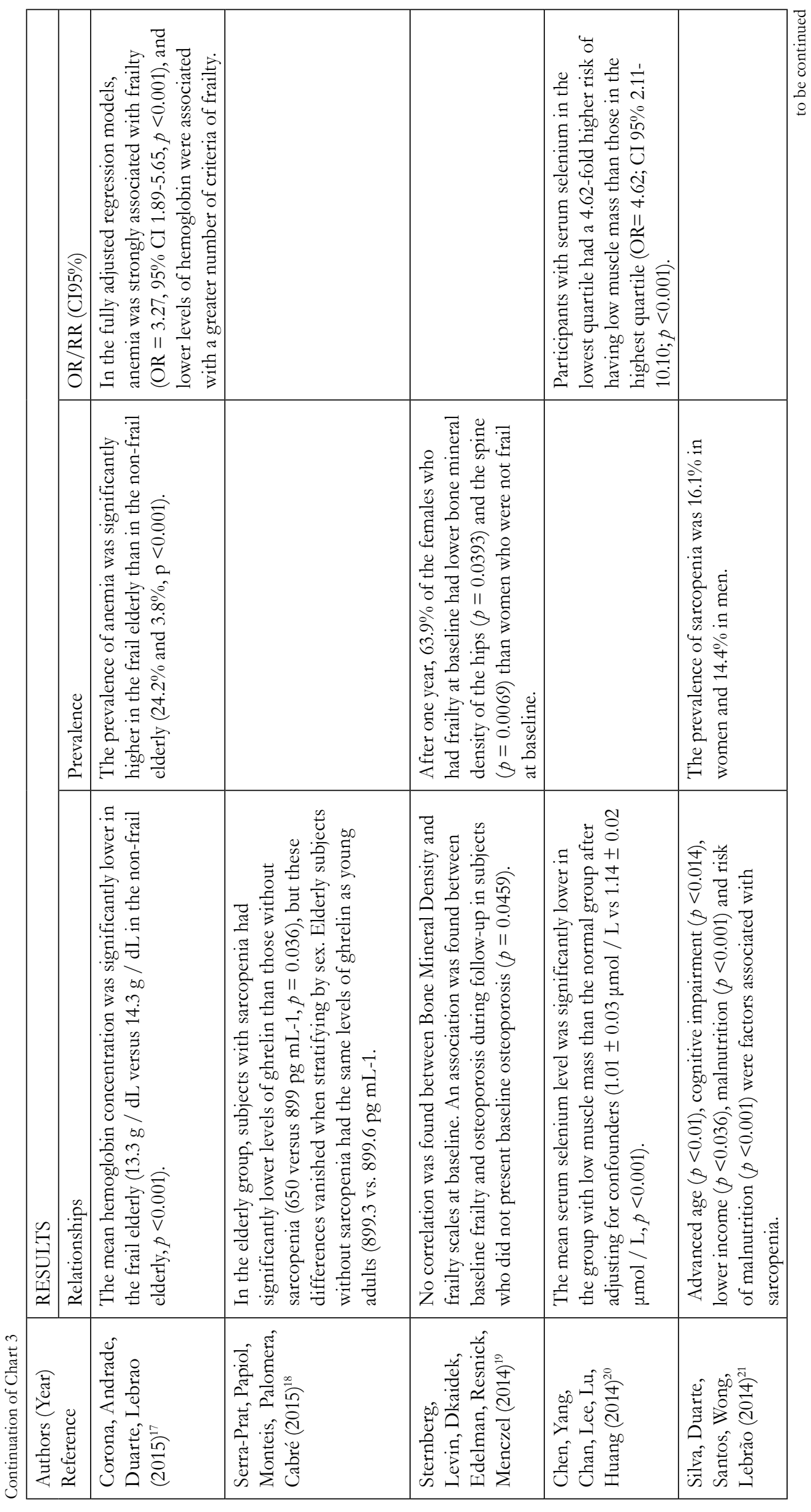




\begin{tabular}{|c|c|c|c|}
\hline & 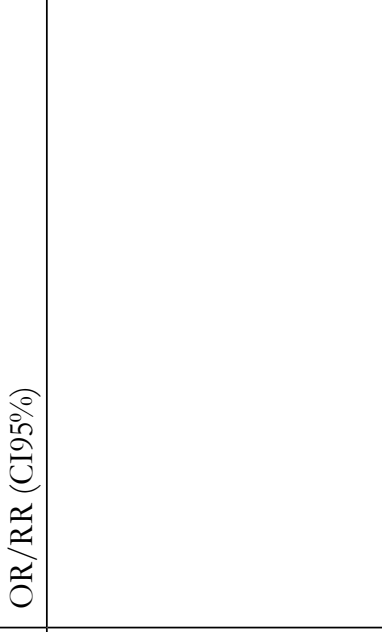 & 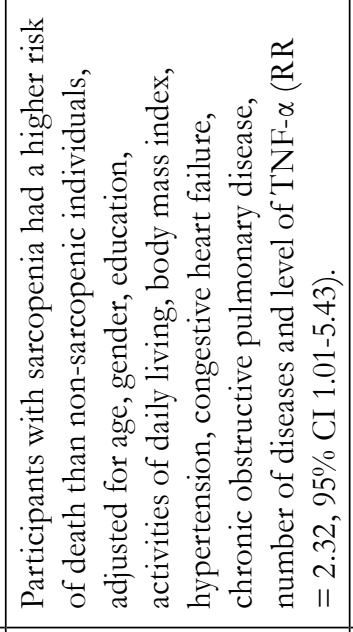 & 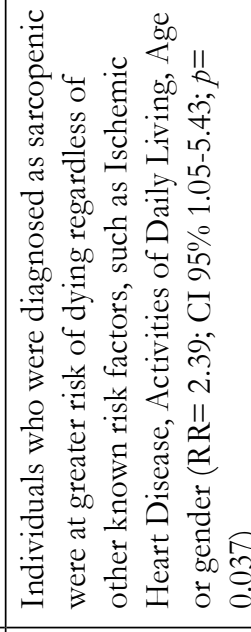 \\
\hline & 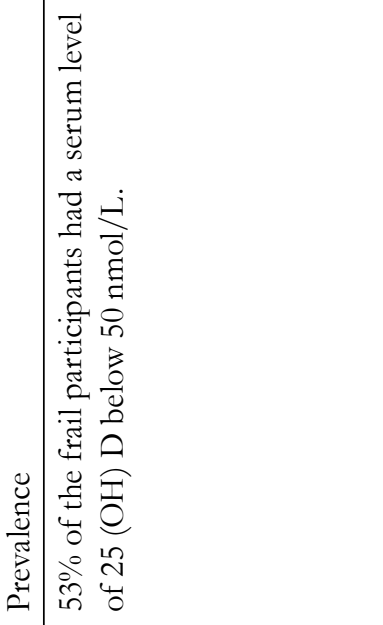 & 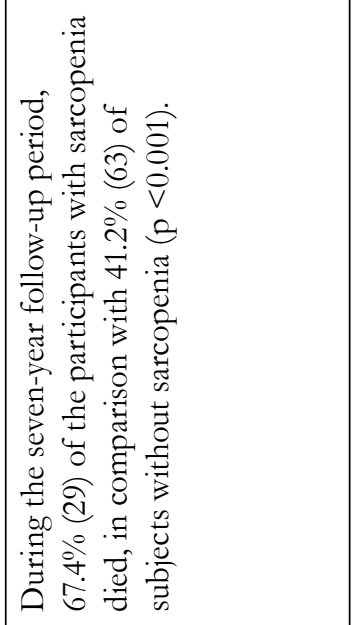 & 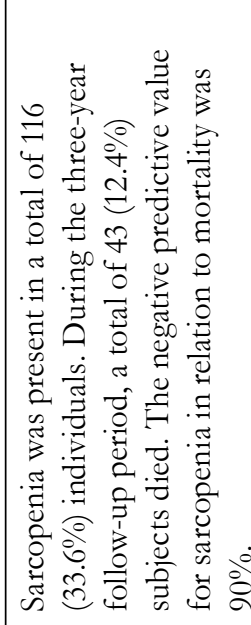 \\
\hline 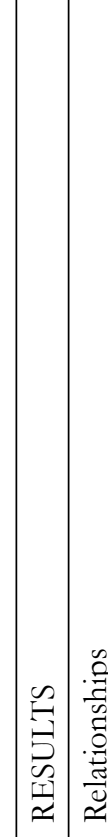 & 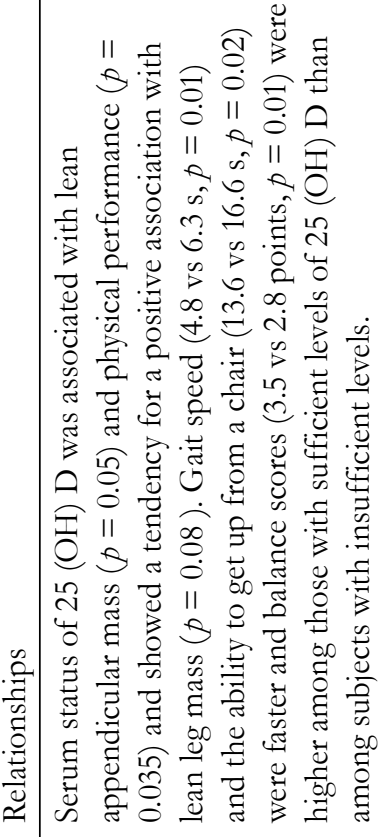 & 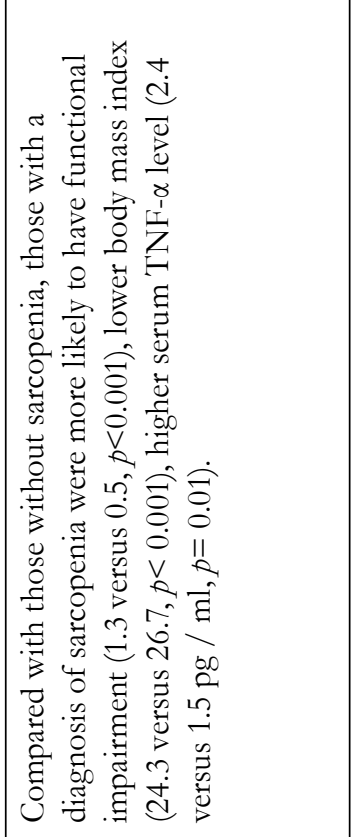 & \\
\hline 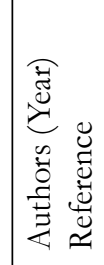 & 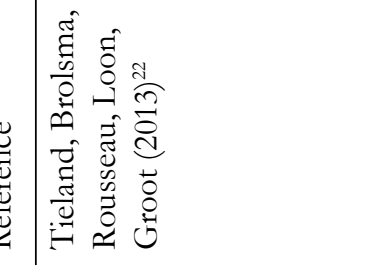 & 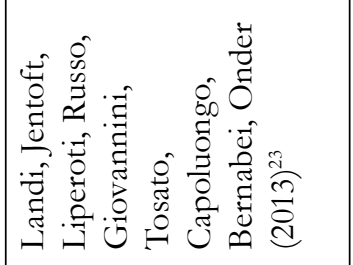 & 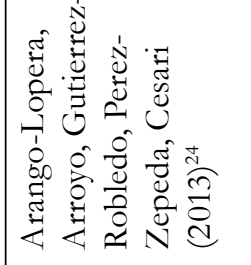 \\
\hline
\end{tabular}


The results show that frailty is associated with several factors such as: sarcopenia ${ }^{16}$, low vitamin D levels ${ }^{22}$, anemia ${ }^{17}$, subclinical hyperthyroidism in men $^{15}$, and a greater evolution of osteoporosis in women ${ }^{19}$. Sarcopenia is associated with poorer quality of life ${ }^{16}$, advanced age ${ }^{21}$, reduced physicalfunctional capacity ${ }^{16,23}$ (greater risk of falls, fatigue when performing activities of daily living and greater probability of functional deterioration), poor nutritional status ${ }^{16,21,23}$ (malnutrition, risk of malnutrition, lower fat mass, lower lean mass and lower body mass index), increased comorbiditie ${ }^{14,16,18,20,21,23}$ (respiratory failure, renal and dizziness, osteopenia and osteoporosis, use of medications, greater number of hospitalizations, inferior cognitive capacity, higher serum TNF- $\alpha$ levels, lower serum levels of selenium and ghrelin); sarcopenia also increases the risk of mortality ${ }^{23,24}$ -

\section{DISCUSSION}

The evidence of the articles analyzed shows that the factors that predispose the individual to frailty are related to immunological dysfunction, neuroendocrine dysregulation and dysfunction in the musculoskeletal system. Among the disorders that occur with these dysfunctions, vitamin $\mathrm{D}$ appears to be a risk factor for frailty. This relationship between vitamin $\mathrm{D}$ and frailty can be explained by three different pathways ${ }^{25}$ related to the three pillars of frailty.

The first pathway is explained by the negative regulation between vitamin $\mathrm{D}$ levels and inflammatory markers ${ }^{25}$, while it is also known that chronic inflammation and immune activation are related to the condition of frailty ${ }^{26}$. In addition, vitamin $\mathrm{D}$ deficiency is associated with chronic inflammatory anemia, through the deregulation of pro-inflammatory cytokine release and the synthesis of hepcidin ${ }^{27}$, which is responsible for the absorption of iron into the duodenum and its release from the stock cells ${ }^{28}$. Studies have shown the relationship between frailty and high serum levels of Interleukin- 6 associated with low levels of hemoglobin and hematocrit ${ }^{29}$ and found a 3.27 times greater chance of anemic elderly persons developing frailty ${ }^{17}$.
The second pathway is related to vitamin D reduction and secondary hyperparathyroidism, as this thyroid disorder increases the levels of parathyroid hormone (PTH), which has been associated with poor physical function and frailty $y^{30,31}$. In addition, the relationship between vitamin D deficiency and elevated PTH levels also appears to be associated with the prevalence of sarcopenia. Research has shown that $41.2 \%$ of people with altered levels of PTH have sarcopenia; while this prevalence declines to $16.2 \%$ for populations with normal levels $(p=0.046)^{32}$. The study by Virgini et $\mathrm{al}^{15}$ also shows the relationship between frailty and other hormones such as Thyroid Stimulating Hormone (TSH) and free thyroxine circulating in the blood (T4). The authors of this study observed that there is a 2.48 times greater chance of the occurrence of frailty in men with subclinical hyperthyroidism when compared with individuals without hormonal alterations. In addition to the hormones already mentioned, one of the selected studies emphasizes the relationship between the hormone ghrelin and sarcopenia, as the sarcopenic individuals presented significantly lower levels of ghrelin than those without sarcopeni $a^{18}$. Ghrelin is an appetite stimulant and inducer of growth hormone (GH), and the low levels of this hormone associated with the anorexia of aging trigger a cascade of events that predisposes the individual to developing sarcopenia ${ }^{33}$.

The third pathway explains the molecular effects that vitamin D can exert on skeletal muscle ${ }^{34}$, influencing calcium flow, the internal regulation of minerals and the signaling pathways of anabolic protein routes ${ }^{35,36}$. In this way, it affects the mass, strength and quality of muscle contraction in the elderly ${ }^{25}$ and causes the presence of sarcopenia in this population. From multivariate regressions, studies have shown that in the sarcopenic elderly the risk of death is 2.39 times higher than among the non-sarcopenic elderly, adjusted for ischemic heart disease, activities of daily living, age or gender ${ }^{24}$; and 2.32 times greater when adjusted for age, gender, education, activities of daily living, body mass index, hypertension, congestive heart failure, chronic obstructive pulmonary disease, number of diseases and level of TNF- $\alpha^{23}$. In addition, the study by Beaudart et $\mathrm{al}{ }^{16}$ found a significant association between frailty and sarcopenia; as $34.2 \%$ of the 
sarcopenic population were diagnosed as frail while only $12.6 \%$ of the non-sarcopenic population suffered from this condition $(p=0.03)$.

It was also observed in this review that the studies demonstrated a relationship between osteoporosis and frailty in women ${ }^{19}$. This relationship can be two conditions, such as the sharing of inflammatory markers through increased C-reactive protein and interleukin- 6 associated with frailty, osteoporosis and sarcopenia ${ }^{37,38}$. The other pathway shared by muscles and bones corresponds to the relationship between PTH and insulin-like growth factor 1 (IGF-1) ${ }^{39}$, which affect bone remodeling ${ }^{40}$ and the reduction in muscle mass and strength ${ }^{38}$, and interact with the regulation of the circulating calcium. Vitamin $\mathrm{D}$ has the role of modulating the calcium pumps in the sarcoplasmic reticulum and sarcolemma, thereby regulating muscle calcium concentrations ${ }^{41}$, assisting in the intestinal absorption of calcium and interfering with bone resorption ${ }^{42}$. Also, it is noted that sarcopenic elderly are 1.8 times more likely to develop osteopenia and osteoporosis ${ }^{14}$.

With scientific evidence showing the relationship between vitamin $\mathrm{D}$ and frailty, serum levels of 25-hydroxyvitamin $\mathrm{D}(25(\mathrm{OH}) \mathrm{D})$ constituted an important biological marker for frailty and should be considered in the follow-up care of the elderly. For this population, values below $50 \mathrm{nmol} / \mathrm{L} 43$ are considered deficient; studies show that serum levels below this value are associated with the reduction of lean appendicular mass and physical performance ${ }^{22}$. Regarding vitamin D supplementation as a form of prevention or treatment for frailty, there are still no interventionist studies with solid evidence on this issue, as evidenced by a current systematic review ${ }^{25}$, in which only effectiveness in gaining muscle strength was proven ${ }^{44}$. Research is still required to study the effects of vitamin D supplementation on the elderly and the repercussions on frailty and sarcopenia, as well as studies that seek to define the optimal treatment modalities, including dose, mode of administration and duration.

Primary care is the entry point of the Unified Health System and aims to prevent disabilities that occur in aging, thus improving health indicators and promoting active aging ${ }^{45}$. Therefore, protocols that assess the conditions associated with frailty in the elderly, aimed at the planning of individual and collective health actions and the early detection of frailty, are essential; as this condition may evolve into dependency and loss of autonomy.

One of the limitations of this systematic review is that the search for articles only covered the last five years, as the themes of sarcopenia and frailty have been discussed in scientific journals for a long time. However, through the articles selected, scientific evidence has been collected that can support primary health care teams in the prevention of frailty among the elderly population. In addition, the review demonstrates the importance of epidemiological studies that evaluate prevalence and identify the causal factors of frailty; as well as studies that monitor the evolution and outcomes of this condition in the Brazilian population, as the majority of studies found involved European and North American elderly persons.

\section{CONCLUSION}

Frailty has been associated with several factors, among which this review highlighted sarcopenia, low vitamin D levels, anemia, subclinical hyperthyroidism in men and a greater evolution for osteoporosis in women. The study also identified an association between sarcopenia and old age and a decline in the following aspects: quality of life, physical-functional capacity, nutritional status and comorbidities; as well as an increased risk of mortality in sarcopenic elderly persons.

This systematic review has shown that low serum levels of vitamin D are associated with frailty and also interfere with factors predisposing this condition. It is therefore important to monitor the serum levels of this vitamin in the elderly population and to suggest new studies related to supplementation in frail elderly persons. At the primary care level, the importance of assessing the conditions associated with frailty in the elderly is emphasized, with the aim of preventing the installation and evolution of frailty, and its repercussions for the quality of life of the elderly and their family. 


\section{REFERENCES}

1. Chaves MM, Rodrigues ALP, Reis AP, Gerzstein, NC, Nogueira-Machado JA. Correlation between NADPH Oxidase and Protein Kinase $\mathrm{C}$ in the ROS Production by Human Granulocytes Related to Age. Gerontology. 2002;48(6):354-9.

2. Izquierdo M, Cadore EL. Muscle power training in the institutionalized frail: a new approach to counteracting functional declines and very late-life disability. Curr Med Res Opin. 2014;30(7):1385-90.

3. Rosenberg IH. Summary comments. Am J Clin Nutr. 1989;50(5):1231-33.

4. Cruz-Jentoft AJ, Baeyens JP, Bauer JM, Boirie Y, Cederholm T, Landi F, et al. Sarcopenia: European consensus on definition and diagnosis. Report of the European Working Group on Sarcopenia in Older People. Age Ageing. 2010; 39(4):412-23.

5. Calvani R, Miccheli A, Landi F, Bossola M, Cesari $\mathrm{M}$, Leeuwenburgh $\mathrm{C}$, et al. Current nutritional recommendations and novel dietary strategies to manage sarcopenia. J Frailty Aging. 2013;2(1):38-53.

6. Mijnarends DM, Schols JM, Meijers JM, Tan FE, Verlaan S, Luiking YC, et al. Instruments to assess sarcopenia and physical frailty in older people living in a community (care) setting: similarities and discrepancies. J Am Med Dir Assoc. 2015;16(4):301-8.

7. Rockwood K, Stadnyk K, MacKnight C, McDowell I, Hebert R, Hogan DB. A brief clinical instrument to classify frailty in elderly people. Lancet. 1999;353(9148):205-6.

8. Fried LP, Tangen CM, Walston J, Newman AB, Hirsch C, Gottdiener J, et al. Frailty in older adults: evidence for a phenotype. J Gerontol Ser A Biol Sci Med Sci. 2001;56(3):146-56.

9. Fried LP, Walston J. Frailty and failure to thrive. In: Hazzard WR, Blass JP, Halter JB, Ouslander JG, Tinetti ME, org. Principles of geriatric medicine and gerontology. New York: McGraw-Hill; 2003. p. 1487-502.

10. Morley JE, Vellas B, Van Kan GA, Anker SD, Bauer JM, Bernabei R, et al. Frailty consensus: a call to action. J Am Med Dir Assoc 2013; 14(6):392-7.

11. Moher D, Liberati A, Tetzlaff J, Altman DG; PRISMA Group. Preferred Reporting Items for Systematic Reviews and Meta-Analyses: The PRISMA Statement. Int J Surg. 2010;8(5):336-41.

12. Loney PL, Chambers LW, Bennett KJ, Roberts JG, Stratford PW. Citical appraisal of the health research literature: prevalence or incidence of a health problem. Chronic Dis Can. 1998;19(4):170-6.
13. Wells GA, Shea B, O'connell D, Peterson J, Welch $\mathrm{V}$, Losos M, et al.The Newcastle-ottawa Quality Assessment Scale (NOS) for assessing the quality of nonrandomised studies in meta-analyses. Clin Epidemiol [Internet]. 2017 [acesso em 22 set. 2017]:12. Disponível em: http://www.ohri.ca/programs/ clinical_epidemiology/nosgen.pdf

14. He H, Liu Y, Tian Q, Papasian CJ, Hu T, Deng HW. Relationship of sarcopenia and body composition with osteoporosis. Osteoporos Int. 2016;27(2):473-82.

15. Virgini VS, Rodondi N, Cawthon PM, Harrison SL, Hoffman AR, Orwoll ES, et al. Subclinical thyroid dysfunction and frailty among older men. J Clin Endocrinol Metab. 2015;100(12):4524-32.

16. Beaudart C, Reginster JY, Petermans J, Gillain S, Quabron A, Locquet M, et al. Quality of life and physical components linked to sarcopenia: The SarcoPhAge study. Exp Gerontol. 2015;69:103-10.

17. Corona LP, Andrade FCD, Duarte YAO, Lebrao ML. The Relationship between anemia, hemoflobin concentration and frailty in Brazilian older adults. J Nutr Health Aging. 2015;19(9):935-40.

18. Serra-Prat M, Papiol M, Monteis R, Palomera E, Cabré M. Relationship between Plasma Ghrelin Levels and Sarcopenia in elderly subjects: a cross-sectional study. J Nutr Health Aging. 2015;19(6):669-72.

19. Sternberg SA, Levin R, Dkaidek S, Edelman S, Resnick T, Menczel J. Frailty and osteoporosis in older women: a prospective study. Osteoporos Int. 2014;25(2):763-8.

20. Chen YL, Yang KC, Chang HH, Lee LT, Lu $\mathrm{CW}$, Huang KC. Low serum selenium level is associated with low muscle mass in the community-dwelling elderly. J Am Med Dir Assoc. 2014;15(11):807-11.

21. Silva AT, Duarte YA, Santos JL, Wong R, Lebrão ML. Prevalence and associated factors of sarcopenia among elderly in Brazil: findings from the SABE study. J Nutr Health Aging. 2014;18(3):284-90.

22. Tieland M, Brouwer-Brolsma EM, NienaberRousseau C, van Loon LJ, de Groot LC. Low vitamin $\mathrm{D}$ status is associated with reduced muscle mass and impaired physical performance in frail elderly people. Eur J Clin Nutr. 2013;67(10):1050-5.

23. Landi F, Cruz-Jentoft AJ, Liperoti R, Russo A, Giovannini S, Tosato M, et al. Sarcopenia and mortality risk in frail older persons aged 80 years and older: results from ilSIRENTE study. Age Ageing. 2013;42(2):203-9. 
24. Arango-Lopera VE, Arroyo P, Gutierrez-Robledo LM, Perez-Zepeda MU, Cesari M. Mortality as an adverse outcome of sarcopenia. J Nutr Health Aging. 2013;17(3):259-62.

25. Bruyère $\mathrm{O}$, Cavalier $\mathrm{E}$, Buckinx $\mathrm{F}$, Reginster JY. Relevance of vitamin D in the pathogenesis and therapy of frailty. Curr Opin Clin Nutr Metab Care. 2017;20(1):26-9.

26. Chen X, Mao G, Leng SX. Frailty syndrome: an overview. Clin Interv Aging. 2014;9:433-41.

27. Monlezun DJ, Camargo Jr CA, Mullen JT, Quraishi $\mathrm{SA}$. Vitamin D status andthe risk of anemia in community-dwelling adults: results from the National Health and Nutrition Examination Survey 2001-2006. Medicine (Baltimore).2015;94(50):1-6.

28. Antunes AS, Canziani MEF. Hepcidina: um importante regulador do metabolismo de ferro na doença renal crônica. J Bras Nefrol. 2016;38(3):351-5.

29. Leng S, Chaves P, Koenig K, Walston J. Serum interleukin- 6 and hemoglobin as physiological correlates in the geriatric syndrome of frailty: a pilot study. J Am Geriatr Soc. 2002;50(7):1268-71.

30. Tajar A, Lee DM, Pye SR, O'Connell $\mathrm{MD}$, Ravindrarajah R, Gielen E, et al. The association of frailty with serum 25-hydroxyvitamin $\mathrm{D}$ and parathyroid hormone levels in older European men. Age Ageing. 2013;42(3):352-9.

31. Visser M, Deeg DJ, Lips P; Longitudinal Aging Study Amsterdam. Longitudinal Aging Study AmsterdamLow vitamin $\mathrm{D}$ and high parathyroid hormone levels as determinants of loss of muscle strength and muscle mass (sarcopenia): the Longitudinal Aging Study Amsterdam. J Clin Endocrinol Metab. 2003;88(12):5766-72.

32. Genaro PS, Pinheiro MM, Szejnfeld VL, Martini LA. Secondary hyperparathyroidism and its relationship with sarcopenia in elderly women. Arch Gerontol Geriatr. 2015;60(2):349-53.

33. Correa-Silva SR, Sá LBPC, Lengyel AJ. Ghrelina e secretagogos do hormônio de crescimento (GHS): modulação da secreção do hormônio de crescimento e perspectivas terapêuticas. Arq Bras Endocrinol Metab. 2008;52(5):726-33.
34. Walrand S. Effect of vitamin D on skeletal muscle. Geriatr Psychol Neuropsychiatr Vieil. 2016;14(2):127-34.

35. Anagnostis P, Dimopoulou C, Karras S, Lambrinoudaki I, Goulis DG. Sarcopenia in postmenopausal women: is there any role for vitamin D? Maturitas. 2015;82(1):56-64.

36. Sanders KM, Scott D, Ebeling PR. Vitamin D deficiency and its role in muscle-bone interactions in the elderly. Curr Osteoporos Rep. 2014;12(1):74-81.

37. Ershler WB, Keller ET. Age-associated increased interleukin- 6 gene expression, late-life diseases, and frailty. Ann Rev Med. 2000; 51:245-70.

38. Espinoza S, Walston JD. Frailty in older adults: insights and interventions. Clevel Clin J Med. 2005;72(12):1105-12.

39. Datta NS. Muscle-bone and fat-bone interactions in regulating bone mass: do PTH and PTHrP play any role? Endocrine. 2014;47(2):389-400.

40. Cherian J, Kenny AM, Taxel P, Lorenzo JA, Dugue G, Kuchel GA. Role of endocrine-immune dysregulation in osteoporosis, sarcopenia, frailty and fracture risk. Mol Aspects Med. 2005;26(3):181-201.

41. Ceglia L. Vitamin D and skeletal muscle tissue and function. Mol Aspects Med. 2008;29(6):407-14.

42. Santos ML, Borges GF. Exercício físico no tratamento e prevenção de idosos com osteoporose: uma revisão sistemática. Fisioter Mov. 2010;23(2):289-99.

43. Institute of Medicine; Ross AC, Taylor CL, Yaktine AL, Del Valle HB (editors). Dietary Reference Intakes for Calcium and Vitamin D. Washington: National Academies Press; 2011.

44. Beudart C, Buckinx F, Rabenda V, Gillain S, Cavalier $\mathrm{E}$, Slomian J, et al. The effects of vitamin D on skeletal muscle strength, muscle mass, and muscle power: a systematic review and meta-analysis of randomized controlled trials. J Clin Endocrinol Metab. 2014;99(11):4336-45.

45. Martins AB, D’Avila OP, Hilgert JB, Hugo FN. Atenção primária a saúde voltada aos idosos: da teoria à prática. Ciênc Saúde Colet. 2014;19(8):3403-16. 